\title{
THE STUDY OF RISK PRODUCTION IN INCREASING OF FARMING RICE PRODUCTIVITY AT KERINCI DISTRICT OF JAMBI PROVINCE, INDONESIA
}

\author{
Malik Adlaida*, Murdy Sa'ad, Nainggolan Saidin \\ Agribusiness Study Program, Faculty of Agriculture, University of Jambi, Indonesia \\ *E-mail: adlaida.malik@unja.ac.id
}

\begin{abstract}
The Risk Analysis of Just and Pope is a mean production function and production variance function, each of which is influenced by the use of inputs in the production process. These models focus on the allocation of inputs that affect toward the increasing or decreasing of production risks. This study aims to determine the allocation of input use and production risks, and formulate a model of allocation of use of production inputs that can produce paddy rice farming production risks are lower in Kerinci district. This study takes four villages purposively with a sample size of 90 farmers. Methods of data analysis using Cobb-Douglas production function, and for the risk function and the production model just and pope. The results showed that the risk was significantly affected by the production of urea, SP36, KCL, and organic fertilizers, insecticides and labor. Input this production is a factor that can reduce the risk (reducing risk factors), while the area of land and the planting season are factors that increase the risk (risk increasing factors). The deciding factor is the productivity of the functions of urea fertilizer and seed use. Both of these production inputs are the inputs production against technical efficiency, potential increase in production by $48 \%$. Policy needs to be done is the assistance of urea fertilizer and seeds right amount, on time, and the right price, so that farmers can allocate both the production inputs in rice farming.
\end{abstract}

\section{KEY WORDS}

Risk, production, input, Just and Pope model.

An activity or activities and decisions taken by businesses or farmers always exposed to various risks. The larger a business that is do then the risk would be even greater. According Debertin (1986), the risk is an event where the outcome of the incident and the probability can be known. Then, according to Ellis (1988) meaningful opportunities expected frequency of an event (the total probability is one), thus the risk is a matter of objective assuming sufficient information is available. In practice, the information is not solely refers to one's knowledge on specific events but rather on a personal level decision makers. In other words, how much confidence the person is on any opportunities that may occur, then the limit of risk changed from the viewing which is objective to the subjective.

In addition to the risk, in an activity also often faced with a situation that called uncertainty. The second term is the risk (risk) and uncertainty (uncertainty) is often used simultaneously. According Debertin (1986) explains the concept of risk and uncertainty separately and use the term uncertainty (uncertainty) associated with the chance (probability). Risk is defined as the probability of occurrence can be determined by a decision maker based on his experience. While uncertainty is defined as the probability of occurrence that can not be known by decision makers.

In the agricultural business is always faced with a situation of risk and uncertainty. Farmers' willingness to accept substantial risk associated with the farmer's attitude. There are farmers who dare to risk, neutral to risk and fear of risk. Most research on agricultural production using the production function does not include the risk factors in these functions. Whereas risk factors including a crucial element in agricultural production decisions, such as how to influence the risk of the application of farming technology. Just and Pope (1979) explains that in analyzing the agricultural business is very important to consider risk factors such as production risks associated with government policy to implement new innovations 
and price risk. Farmers' willingness to accept the risk and uncertainty associated with the farmers' attitude.

In farming, the farmer's decision to allocate the input is strongly influenced by the behavior of the risks must be faced. According to Ellis (1988), the behavior of farmers are grouped into three, namely: (1) those who avoid risk (risk averse), (2) those neutral towards risk (risk neutral), and (3) those who like risk (risk takers), Normally no one wants to enter in an environment full of risk and uncertainty without expectation of reward is greater than the environment that there is no risk and uncertainty. The behavior of farmers who are afraid to risk (risk averse) based not on utility maximization, but maximizing profit expectations, assuming the price and production is stochastic (Just and Pope, 1979).

Therefore, research on the risks associated with a very important decision, especially farmers in production activities. Indications of risk in farming include any changes or variations such as in the production, price and income. Many models are associated with risks such as determining the optimal input on product price risk conditions, input price risk, the risk of quality input and output functions of risk. For example, for a model with a risk of product prices, the decision to plant is highly dependent on the price of the product so that if the low price product will not attract farmers to plant and vice versa.

In general risk analysis using production function which is a mean production function and variance production function, each of which is influenced by the use of inputs in the production process. This model has been used by Walter et al. (2004), in the analysis of production risks. The estimation of the production function can be performed separately between the average production function and the production function variance are both influenced by input factors (such as soil, fertilizers, seeds, labor and pesticides). But according Debertin (1986) incorporate risk factors as a factor affecting the use of inputs. While Just and Pope (1979) look at the risks involved in the production as measured by the variance of output, and suggests using the production function specification. Model Just and Pope focused on the allocation of inputs that can lead to increased or decreased risk. Just frameworks and Pope (1979) assume that the error term in the production function is a risk, while Aigner et al. (1977) assume that the error term is derived from their own risk and inefficiency. In addition, on the model of Just and Pope also did not account for the behavior of producers in the face of risk. Whereas producer behavior in the face of risk affects the allocation or use of inputs and increase its output deals.

\section{METHODS OF RESEARCH}

This study was conducted with the scope of Kerinci regency. Roving Subdistrict Danau Kerinci and Keliling Danau were selected purposively for rice production centers, research was conducted from April to November 2019. Source of data collected included primary data and secondary data. Primary data were obtained from paddy rice farmers collected directly by observation and interview, while the secondary data in this study was obtained from research reports, agencies, and the literature used in this study. Farmer sample size in this study was determined by using a formula of Taro Yamane, or better known by the name of the method Slovin (Sujarweni, 2014), sampling is done by simple random sampling method. Method of analysis of risk data paddy production in irrigated rice and rainfed to see the difference in the level of productivity was tested using homogeneity analysis methods Bartlett-test (Snedecor and Cochran, 1973) with the formula:

$$
\mathrm{Cv}=\frac{\sum\{Y i-\hat{Y}\}^{2}}{N-1}
$$

Where: $\mathrm{Yi}=$ Productivity Currents; $\mathrm{Y}=$ Productivity Potential.

$$
\mathrm{P}\left\{\overline{\mathrm{Y}}-2(\alpha=5 \%) \sqrt{\frac{C v}{N-1}}<\hat{\mathrm{Y}}_{\text {opt }}<\hat{\mathrm{Y}}+\mathrm{Z}(\alpha=5 \%) \sqrt{\frac{C v}{N-1}}=1-\alpha\right\}
$$


The amount of influence on the risk of the use of production inputs were analyzed using multiple linear regression methods heteroscedastic. Heteroscedastic models used are multiplicative model of hetero-scedasticity by maximizing the likelihood function (Just and Pope). The regression model for the effect on productivity and input use on the risk of production in general is written as follows:

$\operatorname{Ln} X b k=\beta 0+\beta 1 \ln \ln Q P N Q B K+\beta 2+\beta 3+\beta 4 \ln \ln Q P P Q P K+\beta 5+\beta 6 Q P O \ln \ln Q D+\beta 7 Q L+$ In In $\beta 8 \beta 9$ JRS + JSP $+\beta 1$ In In In DJ2 DJ1 + $\beta 2+\beta 3 \ln D J 3+B 4+\beta 5$ Dmt4 In In In DV $5+\beta 6 \beta 7$ $D T L 1+\beta 8$ DTL2 In In In DSL1 + $\beta 9$ DSL2 + u04

$\ln \left(\mathrm{uk}^{2}\right)=\ln \sigma_{\left(Y_{i}-\bar{Y}\right)^{2}}^{2}=\mathrm{B} 0+\beta 1 \ln \mathrm{QBK}+\beta 2 \ln \mathrm{QPN}+\beta 3 \ln \mathrm{QPP}+\beta 4 \ln \mathrm{QPK}+\beta 5 \ln \mathrm{QPO}+\beta 6 \ln$ $\mathrm{QD}+\beta 7 \ln \mathrm{QL}+\beta 8 \ln \mathrm{JRS}+\beta 9 \ln \mathrm{JSP}+\beta 1 \ln \mathrm{DJ} 1+\beta 2 \ln \mathrm{DJ} 2+\beta 3 \ln \mathrm{DJ} 3+\beta 4+\beta 5 \mathrm{Dmt} 4 \ln \ln \ln$ DV5 + $\beta 6$ $\beta 7$ DTL1 + + $\beta 8$ DTL2 In In In DSL1 + $\beta 9$ DSL2 + u04

Where: Xbk $=$ Rice productivity $(\mathrm{kg} / \mathrm{ha}) ; \mathrm{yf}=$ Production of rice $(\mathrm{kg}) ; u k^{2}=$ Rice production risk (residual); QBK = The amount of seed paddy $(\mathrm{kg}) ; \mathrm{QPN}=$ Number of urea $(\mathrm{kg})$; QPP = Number SP36 (kg); QPK = The amount of fertilizer $\mathrm{KCl}(\mathrm{kg}) ; \mathrm{QPO}=$ The amount of organic fertilizer (kg; Itr); $\mathrm{QD}=$ Total pesticides (lt); $\mathrm{QL}=$ Total non-family labor (HOK); $\mathrm{JRS}=$ Distance from the fields $(\mathrm{km}) ; \mathrm{JSP}=$ Distance from the means of production $(\mathrm{km})$; $\mathrm{dmt}=$ dummy growing season $\left(\mathrm{D}_{\mathrm{mt}}=1\right.$, the dry season; $\mathrm{Dmt}=0$, the rainy season); $\mathrm{DV}=$ dummy rice varieties $\left(\mathrm{D}_{\mathrm{V}}=1\right.$, improved varieties; $\mathrm{DV}=0$, etc. $)$; $\mathrm{DJ} 1=$ dummy a spacing (DJ1 = 1, $40 \times 10 \mathrm{~cm}$; DJ1 = 0, etc.); DJ2 = dummy a spacing (DJ2 = 1, $40 \times 15 \mathrm{~cm}$; DJ2 = 0, etc.); DJ2 = dummy a spacing (DJ3 =1, $30 \times 20 \mathrm{~cm}$; DJ3 = 0, etc.); DTL1 = dummy Farming $(\mathrm{DTL} 1=1$, irrigated fields; DTL1 = 0, etc.); DTL2 = dummy Farming (DTL2 = 1, irrigated fields; $\mathrm{DTL2}=0$, etc.); $\delta 1 . \delta 9=$ The coefficient of the dummy; Ui = Penganggu mistake (error); in = Regression coefficients (the parameter of each input $i(i=1-9)$.

\section{RESULTS AND DISCUSSION}

Estimation of Production Function and Risk Production of Rice Farming. DurbinWatson stat value of $1.227757<1.7$ and a value Prob Chi Square (9) of 0.2481> $\alpha(0: 05)$, it means that the model is free of autokorelas means no correlation occurs between the residuals on the observation by other observations in the regression model. Normality test results demonstrate the value of the Jarque-Bera at 3.2970 $P$ Value of $0.1923>\alpha(0: 05)$ so that data has been collected in normal distribution or taken from the normal population, Test Multikolieniritas seen from VIF X1-X9 $<10$, it can be stated that there is no multikolieniritas in the model which means there is no linear relationship between the independent variables in the regression model, Value $\mathrm{P}$ Value indicated by the value Prob Chi Square (8) at Obs * Rsquare is equal to $0.2100>\alpha(0.05)$, then there is no problem with Heteroskidastity in the model.

Table 1 - Estimated Production Function and Risk of Rice Production Rice with Dummy in the Regional Research, 2019

\begin{tabular}{lcccc}
\hline \multicolumn{1}{c}{ Variables } & \multicolumn{2}{c}{ Production function } & \multicolumn{2}{c}{ Risk function } \\
& Coefficient & prob & Coefficient & prob \\
\hline QBK_BENIH & 0.23213 & 0.0007 & -0.18634 & 0.0365 \\
QPN_UREA results & 0.13179 & 0.0092 & -0.14577 & 0.0275 \\
QPP_SP36 & 0.12358 & 0.0064 & -0.14264 & 0.0161 \\
QPK_KCL & 0.00296 & 0957 & 0.024833 & 0.7297 \\
QPO_ORGANIK & 0.0426 & 0.2437 & -0.0615 & 0199 \\
QD_OBAT & 0.13887 & 0.0001 & -0.18855 & 0 \\
QL_TENAGA_KERJA & 0.01967 & 0.7207 & 0.020661 & 0.7743 \\
LL_LUAS_LAHAN & 0.26752 & 0001 & 2.825564 & 0 \\
DUMMY & & & 0.215984 & 0 \\
\hline \multicolumn{1}{c}{ R-squared } & 0.88035 & & 0.953175 & \\
\hline
\end{tabular}


Table 1 shows that the results of the estimation model of production risk function provides the coefficient of determination (Adj-R2) is 0.950667 . This thing means diversity of rice production risk can be explained jointly by the factors of production of seed, fertilizer urea, SP36, pic fertilizer, organic fertilizer, insecticide, labor and land. Based on the results of the estimation of the risk function production at Table 1, the function of rice production risk can be predicted by the following equation:

$$
\begin{gathered}
\log Y(\text { risk })=21.16-0.19 \log X 1-\log X 20.15-0.14+0.02 \log X 4 \log X 3 \log X 50.06-0.19+ \\
0.02 \log X 6 \log X 8 \log X 7+2,82-0,21 \text { Dummy }
\end{gathered}
$$

The influence of the use of production factors simultaneously against risks resulting rice production can be determined by using $F$, from the analysis results obtained $F_{\text {count }}$ 379.98 with prob. $0.0000<\alpha(0.01)$, meaning that the independent variables included in the model together significantly affect rice production risk. The results are consistent with the conducted by Zakirin, Yurisinthae and Kusrini (2013) on paddy on tidal land stating that together the variable land, seed, labor, fertilizer urea, TSP fertilizer, herbicides, pesticides, labor, education and age of farmers risks affecting paddy production in tidal land.

Variable seed (QBK) positive and significant impact on rice production and a significant and negative effect on the risk of paddy in the Keliling Danau district. It menas that the more seeds were used in the production process, the production will increase and the risk of wetland rice production continues to decrease, so that the seed variables are factors that reduce the risk (reducing risk factors). Seed variable has a value prob. $0.0365<\alpha(0.05)$, meaning that the variable seed significantly affect rice production risk, The results of this study are not consistent with research Suharyanto (2012), which suggested that the risk concerning the use of seed production did not significantly affect the risk of decline in production of paddy rice farming. While research Zakirin et al (2013) revealed an increase in the use of quality seeds to some extent will increase the population of the plant, thus increasing productivity and ultimately can reduce the risk of production. The use seed in the study area are in accordance with recommendation $25 \mathrm{~kg} / \mathrm{ha}$ with the recommendations given in the range of $20-30 \mathrm{~kg} / \mathrm{ha}$. By using the appropriate varieties on irrigated rice field in Jambi Province.

Variable urea (QPN) positive and significant impact on rice production and a significant and negative effect on the risk of paddy. That is, the more urea used in the production process, the production will increase and the risk of wetland rice production continues to decrease, so that urea fertilizer variables are factors that reduce the risk (reducing risk factors). Urea fertilizer variable has a value prob. $0.0275<\alpha(0.05)$, meaning that the variable Urea significantly affect rice production risk. The results are consistent with research Fauziyah (2010) in which chemical fertilizers such as Urea lowers the risk of production.

Variable SP36 (QPP) positive and significant impact on rice production and a significant effect and a negative against the risk of rice production. It means that more and more SP36 used in the production process, the production will increase and the risk of rice production continues to decrease, so that the variable SP36 is a factor that reduces the risk (reducing risk factors). Variable fertilizer has a value prob. $0.0161<\alpha(0.05)$, meaning that the variable SP36 significantly affect rice production risk. The results are consistent with research Apriana (2015) states that the variable is a variable production of chemical fertilizers that can reduce the risk of production. The use of fertilizers is overstated by 125.78 $\mathrm{kg} /$ ha proved that the use of chemical fertilizers, which can reduce production risks.

Variable KCL fertilizer (QPK) positive effect but not significant effect on rice production and value-negative but not significant effect on the risk of rice production. It means, KCL fertilizer used in the production process can not be a significant influence on the results of production and results of rice production risk. Variable fertilizer has a value prob. $0.7297>\alpha$ (0.05), meaning that the variable KCL fertilizer did not significantly affect the risk of rice production, The results are consistent with research Suharyanto (2012) suggests that the risk of production on fertilizer use KCL no significant effect on decreasing the risk of paddy rice farm production. KCL fertilizer use in the study area does not match the dose that is equal to 
$40.33 \mathrm{~kg} / \mathrm{ha}$ is supposed equal to $75 \mathrm{~kg} / \mathrm{ha}$ so there is no effect in the reduction of production risks.

Variable organic fertilizer (QPO) positive effect no significant effect on rice production and a negative value does not significantly influence the risk of rice production. It means, organic fertilizers are used in the production process can not be a significant influence on the results of production and results of rice production risk. Variable fertilizer has a value prob. $0.1990>a(0.05)$, meaning that the variable organic fertilizer did not significantly affect the risk of rice production. The results of this study are not consistent with research Suharyanto (2012) suggests that the risk of production on the use of organic fertilizer had no significant effect on reducing risk of paddy rice farm production. Dose use of organic fertilizers are still below the recommended dosage of $866.77 \mathrm{~kg} / \mathrm{ha}$ is supposed to $2000 \mathrm{~kg} / \mathrm{ha}$ of organic fertilizer not cause significant effect on decreasing the risk of production.

Variable insecticide (QD) positive and significant impact on rice production and a significant effect and a negative against the risk of rice production. It means that more insecticide that is used in the production process, the production will increase and the risk of rice production continues to decrease, so that the variable insecticide is a factor that reduces the risk (risk reducing factors). Variable fertilizer has a value prob. $0.00<(0.05)$, meaning that the variable insecticide significantly affect rice production risk. The analysis also in line with Puspitasari (2011) which states that the pesticide is a risk reduction factor. Spraying is done when the pest population by farmers have increased too.

Variable labor (QL) is positive and significant effect on rice production and rice production risk. It means that production and rice production risks no significant effect on the results of production and results of paddy rice production risk. Variable labor has a value prob. 0.7743> a (0.05), meaning that labor did not significantly affect the risk of rice production, The results are consistent with research Suharyanto (2012) suggests that the risk of production regarding the use of Labor did not significantly affect the risk of decline in production of paddy rice farming.

Variable land area (LL) positive and significant impact on rice production and the risk of rice production. It means the greater the area of land used in the production process, the production will increase and the risk of rice production is increasing, so the variable land area are factors that increase the risk (risk increasing factors). Variable land has a value prob. $0.00<\alpha(0.05)$, meaning that the land area of very significant effect on the risk of rice production, these results are consistent with research Apriana (2015) which revealed the land input is the risk icreasing input. The addition of the land area which is not offset by the technology component in rice cultivation will increase the risk of production.

Dummy variable MT shows the value of the parameter coefficient of 0,215984 with a smaller probability valueof 0.05 , which means that the production function dummy very significantly between paddy rice farm in the rainy season and dry season. In the rainy season the level of Neck Blast disease caused by high rainfall and a lack of sunlight, but it can be overcome with the use of disease-resistant varieties such as ciherang used in the study area. According Satoto et al., (2013) some efforts to be made to reduce the gap in outcomes between seasons among others determine the prevalence of pests and diseases, specific varieties charted well on wet and dry seasons. For example, the recommendation that the technology component of fertilizer, plant spacing, irrigation and pest and disease management.

\section{CONCLUSION}

Use of production inputs are all in the category below the recommended dose recommendation. Paddy rice farm management is still relatively traditional because of the lack of technology application as directed. Factors of production of seed, fertilizer urea, SP36, insecticides and organic fertilizer production is a factor that can decrease the variety of rice production, so that the fifth factor of production is a factor that can reduce the risk of production (reducing risk factors). Increased use of seed, fertilizer urea, SP36, and insecticides can reduce the risk of rice production significantly while reducing the risk of 
organic fertilizer rice production is not real. Factors KCL fertilizer production, organic fertilizer and labor are factors that can increase rice production variations, so that the third factor of production is a factor that can increase the risk of production (increase of risk factors). Increased use of these three factors can increase the risk of rice production is not real. Increased productivity can be done with the application of appropriate technology, expanding plantations and rice areas with increased cropping index (IP), suppress the yield loss at harvest and post-harvest. Improve the stability of the results of the implementation of integrated crop management, pressing the intermediate results of productivity at the farm level productivity research results and reduce the risk of production through the application of the technology transfer process specification and support local farming capital.

\section{REFERENCES}

1. Apriana, Natasa, Anna Fariyanti and Burhanuddin. 2019. Preferensi Risiko Petani Padi Di Daerah Aliran Sungai Bengawan Solo, Kabupaten Bojonegoro, Provinsi Jawa Timur. Jurnal. Program Studi Agribisnis, Sekolah Pascasarjana, Institut Pertanian Bogor, Bogor.

2. Aigner, D.J., C.A.K. Lovell, and P. Schmidt. 1977. Formulation and Estimation of Stochastic Frontier Production Function Models. Journal of Econometrics. 6:21- 37.

3. Debertin, D.I. 1986. Agricultural Production Economics. New York: Macmillan Publishing Company.

4. Ellis, F. 1988. Peasent Economics: Farm Household and Agricultural Development. Cambridge University Press, Cambridge.

5. Puspitasari, Debrina. 2011. Analisis Faktor-Faktor yang Mempengaruhi Risiko Produksi Mentimun (Cucumis sativus L) di Desa Citapen Kecamatan Ciawi Kabupaten Bogor. Skripsi. Fakultas Ekonomi and Manajemen. Institut Pertanian Bogor. Bogor.

6. Satoto, Y. Widyastuti., U. Susanto., M. J. Mejaya. 2013. Perbedaan hasil padi antar musim di lahan sawah irigasi. IPTEK Tanaman Pangan 8 (2): 55-61

7. Snedecor, George W, and W.G. Cochran. 1973. Statistical Methods. Sixth Edition. Ames, lowa, USA: The lowa State University Press.

8. Suharyanto, Jemmy Rinaldy, Nyoman Ngurah Arya. 2015. Analisis Risiko Produksi Usahatami Padi Sawah di Provinsi Bali. Vol. 1 No.2

9. Sujarweni, V Wiratna. 2014. Metodologi Penelitian Lengkap Praktis and Mudah Dipahami. Pustaka Baru Press, Yogyakarta.

10. Walter, J.T., R.K. Roberts, J.A. Larson, B.C. English and Howard. 2004. Effects of Risk, Disease, and Nitrogen Source on Optimal Nitrogen Fertilization Rates in Winter Wheat Production. Paper. Southern Agricultural Economic Association. Tulsa, Oklahoma.

11. Zakirin, M. E. Yurishinthae and N. Kusrini. 2013. Analisis Risiko Usahatani Padi Pada Lahan Pasang Surut di Kabupaten Pontianak. Jurnal Social economic of Agriculture 2 (1): 75-84. 